\title{
International Perspectives on Family Policies
}

\author{
Mihaela Robila
}

Published online: 5 October 2011

(C) Springer Science+Business Media, LLC 2011

While the important role of the family in society has been recognized everywhere in the world, it also needs to be substantiated through comprehensive and effective family policies. Family policies have been defined as government activities that are designed intentionally to support families, enhance family members' well-being, and strengthen family relationships (Bogenschneider 2006; Zimmerman 2001). A system of explicit and institutionalized family policy implies legal recognition of the family as a social institution contributing to social cohesion. As such, explicit family policies need to be recognized by governments through development, implementation and evaluation mechanisms.

The literature on family policy in the international arena is limited and, when it exists, it is hard to locate. The major goal of this Special Section on International Perspectives on Family Policies was to fill gaps in the literature on family policies internationally and to enrich the field. It also strives to provide data on family policies in countries about which there is limited information, to present family policies and programs from different countries, and their effectiveness and shortcomings. It also provides policymakers with background data on the importance of family policies and the importance of using a family perspective in policy making, as well as recommendations for improvements.

This Special Section presents a wide array of family policies in different countries, covering a broad geographical area, with two articles on Africa (Sierra Leone,

\section{Robila ( $\square)$}

Department of Family Nutrition and Exercise Sciences, 306 F Remsen Hall, Queens College, City University of New York, 65-30 Kissena Blvd., Flushing, NY 11367-1597, USA

e-mail: Mihaela.Robila@qc.cuny.edu
Kenya), three on Europe (Sweden, Eastern Europe, Turkey), one on Asia (South Korea), two on South America (Brazil, Colombia, Ecuador), two on North America (Canada), and two with cross-continental coverage. There is also diversity in terms of topics, with some articles presenting reviews of family policies in general, while others focus on work-family balance, parental leave, child care policies, same-sex marriages, international adoption, or HIV prevention policies.

Family policies in Africa are discussed in two articles focused on Sierra Leone and Kenya. Africa is one of the regions about which there is limited research on family policies in international forums. In The Evolution of Family Policies in Post Conflict Sierra Leone, Adeyinka Akinsulure-Smith examines the development of family policy in post-conflict Sierra Leone and the challenges faced by the legal system to consistently address the needs of family members. Recent government initiatives aimed at supporting and enhancing the well being of Sierra Leonean families are also discussed. In Family Impact Analysis of Section 6 (Sexual Transmission) of The Kenya HIV and AIDS Prevention and Control Act, no. 14, 2006, Dorothy Rombo and Jane Rose Muthoni Njue present family impact analysis of Section 6 of the Prevention Act, which focuses on the secondary and tertiary transmission of HIV targeting those living with HIV.

Family policies in Europe are discussed in three papers focused on Sweden, Eastern Europe and Turkey. In Do Father-Friendly Policies Promote Father-Friendly ChildRearing Practices? A Review of Swedish Parental Leave and Child Health Centers, Michael Wells and Anna Sarkadi review the literature on Swedish parental leave and societal attitudes of father involvement in Child Health Centers. Sweden has been considered as having one of the most generous and egalitarian parental leave policies in the 
world. Fathers are permitted to take 10 days of paternity leave after their child is born plus 2 months of leave. The authors indicate that although Sweden's parental leave policy promotes father involvement, societal attitudes and norms (e.g., corporate, financial attitudes) interfere with greater levels of father involvement. In Family Policies in Eastern Europe: A Focus on Parental Leave, Mihaela Robila provides a review of the most relevant family policies in this region. Using feminist and family systems theoretical perspectives, she also provides an in-depth examination of childcare policies with a focus on parental leave. Maternity, paternity, and parental leave and childcare services in the region are explored. In Review of Explicit Family Policies in Turkey from a Systemic Approach, Asli Carkoglu, Nilufer Kafescioglu and Asli T. Akdas Mitrani evaluated the status of family policies, focusing on the Turkish Civil Code, the law on Protection of the Family, relevant parts of the labor law, Penal Code and the healthcare policy. Turkey has been going through rapid and extensive change in policies and regulations which have stirred much public debate.

In Family Policy in South Korea: Development, Current Status, and Challenges, Meejung Chin, Jaerim Lee, Soyoung Lee, Seohee Son, and Miai Sung provide the case study of South Korea as an example of family policies in Asia. Their focus is on three areas of family policy: (a) work-family policies, (b) a healthy family policy and (c) a policy for multicultural families.

Family policies in South America are discussed in two papers, one on Brazil and the other on Columbia and Ecuador. In Families, Gender Relations and Social Change in Brazil: Practices, Discourse, Policy, Miriam Adelman and Mariana Corrêa de Azevedo discuss three different areas in which policies on gender and the family have been debated and formulated in Brazil: the Maria da Penha Law on domestic violence, efforts on the legalization of abortion and a bill introduced to give legal status to same-sex relationships. In Family Policy Initiatives in Latin America: The Case of Colombia and Ecuador, Sonia Carrillo, Karen Ripoll-Núñez and Paul L. Schvaneveldt discuss major policy initiatives oriented to improve the living conditions of economically disadvantaged families in both countries. The authors provide a description of the major goals of existing family policy programs, their operation, and evaluation, as well as a discussion of similarities and differences in family policy development in Colombia and Ecuador.

Family policies in North America are presented in two papers focused on Canada. In Canada's Same-Sex Marriage Law: Exception to or Exemplar of Canada's Family Policy? Hilary Anne Rose discusses the fact that Canada does not have a nationally coordinated family policy due to its decentralized government (i.e., federal and provincial, as well as territorial, governments) and other factors (e.g., different traditions of common law in English Canada and civil law in Quebec) and focuses on a recent addition to Canada's family policy which is Bill C-38, The Civil Marriage Act (2005), the law legalizing same-sex marriage.

In Who Says What Election Coverage and Sourcing of Child Care in Four Canadian Dailies, Ann Rauhala, Patrizia Albanese, Carolyn Ferns, Denise Law, Aleysha Haniff, and Lyndsay MacDonald examine childcare policies in Canada. The authors mapped articles about child care in four major Canadian dailies between 2000 and 2008 and found that the coverage increased in 2000 and 2005-2006 during federal elections, and that newspapers' ideological views were apparent in their choice of sources and focus.

Finally, the Special Section includes two papers on topics with broad international relevance, one on international adoption and one on childcare. In Does The Hague Convention on Intercountry Adoption Adequately Protect Orphaned and Vulnerable Children and Their Families? Karen Smith Rotabi and Judith L. Gibbons evaluate the strengths and the weaknesses of the Convention in achieving this purpose and in protecting birth families. The authors use the case study example of the United States' implementation of the Hague requirements to reveal several weaknesses with respect to non-Convention countries as sending nations, underlining that international birth families, especially birth mothers giving consent to an adoption, are often vulnerable because of a lack of power and different cultural understandings of the nature of family and adoption. In Who Cares for the Children? Lessons from a Global Perspective of Child Care Policy, Maegan Lokteff and Kathleen W. Piercy examine the interrelatedness of child care policy and national ideologies of family in several industrialized countries (France, Germany, Japan, South Korea, Belgium, the Nordic countries, and the United States), arguing that a nation's ideology and vision of family often drive child care policies, while child care policies in turn support a nation's ideology.

This Special Section on International Perspectives on Family Policies provides a comprehensive collection of analysis of policies around the world. It also underlines the importance of developing explicit family policies, and their implementation and evaluation. Although there are different challenges for each of these components due to financial resources, political ideologies, or traditions in every single country, it is important for Governments to recognize and support the importance of such a process. 


\section{References}

Bogenschneider, K. (2006). Family policy matters: How policymaking affects families and what professionals can do. Mahwah, NJ: Lawrence Erlbaum.
Zimmerman, S. L. (2001). Family policy: Constructed solutions to family problems. Thousand Oaks, CA: Sage. 